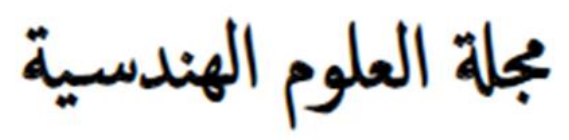

\title{
Management of Delay Factors in Construction Projects in Sudan
}

\author{
Sarah Abdul Aziz Mohamed ${ }^{1, *}$ and Osama Mohamed Ahmed Adam ${ }^{1}$ \\ 1 Civil Engineering, Sudan University of Science $\mathcal{E}$ Technology, Khartoum, Sudan \\ * Corresponding author: Sarah Abdul Aziz Mohamed (e-mail: Saraaziz 80@yahoo.com).
}

Article history: Received 15 March 2020, Received in revised form 4 November 2020, Accepted 11 November 2020

\begin{abstract}
The research aimed to find out and analyze the main causes of delay in construction projects. Just as so how most things are; an unforeseen delay on a construction site is inevitable. The research was designed to identify the possible causes of delay at construction projects from the literature review and previous studies which there are over than thirty causes of delay were displayed, then these causes tested by the analyzing the data and information that were collected from clients, consultants and contractors, researcher conduct site visits to interpretation the causes of delay that emerged during the implementation of the project. The analysis of correspondences letters between project parties; contractor, client, and consultant lead to characterize investigate are project finance, design changes, fluctuation of prices and incomplete design. The research defines who is responsible and type of delay in addition to the discussion of effects, risks, and mitigating of delay. Finally the research concluded with Recommendations such as security funding for the project at the project preparation stage, the contractors should be classified according to the experience which commensurate with the size of the project, The application of value engineering to avoid in complete design problems, it's also strongly recommended future researchers to focus on building construction projects in other parts of the country since this was limited only to the capital city Khartoum through the case study
\end{abstract}

Keywords: Delay, Construction, Project.

\section{INTRODUCTION}

The construction industry in Sudan is an important sector due to its enormous contribution to the country's economic development. However due to the geographical, political, social and economic situation of the country, many construction projects are prone to many factors of delay. These delay factors can only be avoided by first identifying the factors and their sources.

Several factors fall responsible for this setback, but the two most common are due to either confusion or lack of communication. In an effort to evade that, most contractors calculate the additional amount of the expected time to be wasted and add it within the whole time schedule

\section{created. [1], [2]}

So at first, one has to know how well every side in the project should be managed in order to have control over the time. In construction projects; the set of objectives that should be accomplished rely on implementing a series of operations which are subject to resource constraints. [3]

Potential conflicts are always present, between the stated objectives with regard to scope, cost, time and quality, and the constraints imposed on both human and financial resources. After discovering which factor is responsible for the delay, those conflicts can then be well judged so they can be resolved at the onset of a project by making the necessary tradeoffs or creating new alternatives [4]. 
TABLE1. COMMON DELAYS

\begin{tabular}{|c|c|c|}
\hline Client Driven Delay & Contractor Delays & External Consultant Delays \\
\hline $\begin{array}{l}\text { 1- Possible changes to initial design } \\
\text { 2- Unforeseen financial trouble } \\
\text { 3- Slow to make decisions } \\
\text { 4- Unclear about their ultimate goals } \\
\text { and desires }\end{array}$ & $\begin{array}{l}\text { 1- Overbooked on other jobs } \\
\text { 2- Poor management skills } \\
\text { 3- Poor communication } \\
\text { 4- Shortfall in number of subcontractors }\end{array}$ & $\begin{array}{l}\text { 1- Architect, engineer or other } \\
\text { consultant. } \\
\text { 2- Timely delivery of project } \\
\text { information } \\
\text { 3- Build-ability of design } \\
\text { 4- Difficulty in communication } \\
\text { 5- Priority on construction time } \\
\text { 6- Priority to other projects }\end{array}$ \\
\hline
\end{tabular}

\subsection{Research problem}

Delay in construction projects lead to great losses in time and cost, which not only do they effect the project parties, but also the economy of the country as well. So when a delay occurs it should immediately be addressed, so as to determine what is responsible for it. There are four levels of conflict that take place, starting with arbitration that might cause appeal which may lead to claim ending in a disagreement that can go out of hand and in to a complicated situation that can stop the whole work.[5]

\subsection{Objective of Research}

1- Discovering the common factors which cause the delays in site projects

2- Adopt a method to be followed in the construction projects to reduces the delays in site projects

\section{MATERIAL AND METHODS}

\subsection{Construction Delays}

Delay has negative effects on different aspects of a project, including time, quality, cost and safety. In the projects with long-term delays, the plan lose its economic justification, which may cause terminated projects, if the executor was private sector or decrease quality and safety to prevent more financial loses, if the executor was public sector. Negative effects of delay in projects include legal problems between employer, contractor and consultant; decrease of productivity and revenue; unfinished projects table 1. [6], [7]

\subsection{Project Conditions}

1. Function of end use (office, residential, etc...) and the additional restrictions that come with

2. Complexity

3. Location

\section{Access \\ 5. Power availability [8]}

\section{LITERATURE REVIEW}

\subsection{Theoretical background}

The construction process is a complex undertaking. It involves many different activities and participants from initial planning through execution. The requisite tasks, and the roles and responsibilities of the owner, architect engineers, construction managers, contractors, and subcontractors can be organized in a number of different ways to deliver a construction project. Despite these many options, building a major construction project today without experiencing schedule delays and cost overruns is often the exception. While there are many factors that can contribute to these poor results, there are two key success factors: effectively managing time with resources and change. [8]

Managing the time factor can be expensive, fraught with pressures, and subject to much uncertainty. Key factors having an influence on successful project delivery include the use of overly complex scheduling specifications, construction brokering by the contractor, errors and omissions, differing site conditions, user changes, and inadequate time extensions. These can be compounded by reservation of rights for delay, cumulative impacts, and ignoring possible completion date waivers. Further, there is still uncertainty and misunderstanding that remains in terms of what constitutes acceptable standards of proof for excusable delay and impacts. While computers and scheduling software have greatly increased the potential for enhanced scheduling capabilities, they have also contributed to a variety of user quality problems. The situation is often compounded by failure of both the Owner 
and Contractor to recognize from the start the need for timely resolution of delays and keeping the schedule up to date by reflecting actual performance and delays as they occur.[9],[10]

\section{RESULTS ANALYSIS AND DISCUSSIONS}

The qualitative data were generated from literature review, to measure the project performance while quantitative data were generated from questionnaire survey, and were analyzed using average index technique. The summary of the data analysis will be tabulated in the next section and the result will be used as the basis for further discussion in the next chapter.

The developed questionnaire was distributed in a sample containing thirty (30) targeted respondents within the locality of Khartoum contractors.

The data were collected from questionnaires survey and then analyzed in order to determine the critical factors affecting all project stages.

$53.3 \%$ of projects used unit price contracts, 26.7 $\%$ used sum lump contracts and $13.3 \%$ used cost contract as shown in table (1)

Construction contracts lay out the rights and responsibilities of the contractor and the project owner. There are a variety of construction contracts, and depending on the type, one party may benefit from a specific type of contract than

TABLE (1): CONTRACT TYPE

\begin{tabular}{l|l|l|l|l|}
\hline \hline \multicolumn{6}{l}{ Types of contract in the project } & Frequency \\
\hline \multicolumn{2}{l}{ Cumulative Percent } & Valid Percent & Percent & Valid \\
\hline 53.3 & 53.3 & 53.3 & 16 & Unit price contract \\
\hline 66.7 & 13.3 & 13.3 & 4 & Cost contracts against expenses return ratio \\
\hline 93.3 & 26.7 & 26.7 & 8 & Total price contract \\
\hline 96.7 & 3.3 & 3.3 & 1 & Targeted cost contracts \\
\hline 100.0 & 3.3 & 3.3 & 1 & Other \\
\hline \hline & 100.0 & 100.0 & 30 & Total \\
\hline
\end{tabular}

the other parties. Each contract carries with it advantages and disadvantages that may benefit the contractor or the owner, but half of the projects in Sudan deal with Unit price because it is the most effective in changing order and additional works by simply pricing the new order as the same item preceding. The researcher's opinion is that it's suitable and very fair for both sides.

TABLE :( 2) DOCUMENT DELAY

\begin{tabular}{l|l|l|l|l|}
\hline \hline \multicolumn{2}{l}{ If answer was No, then delay in documents' availability was due to: } & \multicolumn{2}{l}{} \\
\hline Cumulative Percent & Valid Percent & Percent & Frequency & \multicolumn{2}{l}{ Valid } \\
& & & & \multicolumn{2}{l}{ Owner } \\
\hline 40.0 & 40.0 & 40.0 & 12 & Contractor \\
\hline 46.7 & 6.7 & 6.7 & 2 & Consultant \\
\hline 50.0 & 3.3 & 3.3 & 1 & n/a \\
\hline 96.7 & 46.7 & 46.7 & 14 & Owner \& Consultant \\
\hline 100.0 & 3.3 & 3.3 & 1 & Total \\
\hline \hline
\end{tabular}

$40 \%$ said the delay is caused by the owner, $6.7 \%$ said it occurred because of contractor and $46 \%$ is missing data.as shown in table (2)

The owner's familiarity with the construction process and level of in house management capability has a large influence over the amount of outside assistance required during the process and may guide the owner in determining the appropriate project delivery method. An owner must make an assessment of its ability to properly perform under the various delivery methods. 
TABLE (3): CONTRACT TYPE DELAY

Does the type of contract have an effect on the project delay

\begin{tabular}{l|l|l|l|l|r}
\hline Cumulative Percent & Valid Percent & Percent & Frequency & \multicolumn{2}{|c}{} \\
\hline 43.3 & 43.3 & 43.3 & 13 & Yes & \multirow{2}{*}{ Valid } \\
\hline 100.0 & 56.7 & 56.7 & 17 & No & \\
\hline \hline & 100.0 & 100.0 & 30 & Total & \\
\hline
\end{tabular}

$73 \%$ of the respondent answered the decisions

More than half; $56.7 \%$ think the type of contract doesn't cause in delaying the project, and 43.3\% said the type of contract does affect.as shown in table (3).

Construction contracts lay out the rights and responsibilities of the contractor and the project owner. There are a variety of construction contracts, and depending on the type, one party may benefit from specific type of contract more than the other. Each contract carries with it advantages and these which may benefit the contractor or the owner. So in Sudan the most preferred type of contract is the unit price.

TABLE (4): CORRECTIVE DECISION

\begin{tabular}{l|l|l|l|l|l}
\hline \hline \multicolumn{2}{c}{ Were corrective decisions made regarding the acts causing delay } \\
\hline Cumulative Percent & Valid Percent & Percent & Frequency & \multicolumn{2}{|c}{ Valid } \\
\hline 73.3 & 73.3 & 73.3 & 22 & Yes & No \\
\hline 90.0 & 16.7 & 16.7 & 5 & Sometimes \\
\hline 100.0 & 10.0 & 10.0 & 3 & Total & \\
\hline
\end{tabular}

This is extremely useful when considering that the number of alternatives can be high. Additionally the use of the model is expected to provide more reliable assessment of the risk associated with the various alternatives.

$30 \%$ answered all the resources were available in time, while $46.7 \%$ said they were not.as shown in table (5).
You now need to construct a resource plan, identifying all the resources needed to complete the project, e.g. labor, equipment and materials. You should also produce schedule indicating when each resource will be used and note any assumptions and constraints made during the resources planning process.

TABLE (5): AVAILABLE ResOURCES

\begin{tabular}{l|l|l|l|l|l}
\hline \hline \multicolumn{6}{l}{ Were the resources available in the project } \\
\hline Cumulative Percent & Valid Percent & Percent & Frequency & \multicolumn{1}{|c}{ Valid } \\
\hline 30.0 & 30.0 & 30.0 & 9 & Yes \\
\hline 76.7 & 46.7 & 46.7 & 14 & No \\
\hline 100.0 & 23.3 & 23.3 & 7 & Sometimes \\
\hline & 100.0 & 100.0 & 30 & Total & \\
\hline \hline
\end{tabular}

Many of the resources required should already be listed in the business case, terms of reference and project plan. For a small project it is sufficient to take each activity listed in the project business case, terms of reference and project plan. For a small project it is sufficient to take each activity listed in the project plan and assign a resource to it. This can be done using a program like Microsoft project, primavera.

$43.3 \%$ of projects used local material, $26.7 \%$ used imported and $26.7 \%$ used both types.as shown in table (6)

With prices of building materials going through the roof with every day passing, potential builders are faced with a dilemma on how to procure quality materials at cost-friendly prices. Opting to import materials instead of locally buying them could greatly cut down one's costs but it is not without kinks. 
TABLE (6) MATERIAL TYPE

\begin{tabular}{l|l|l|l|l|l}
\hline \hline \multicolumn{6}{l}{ What was the type of material used } \\
\hline Cumulative Percent & Valid Percent & Percent & Frequency & \multicolumn{1}{c}{ Valid } \\
\hline 44.8 & 44.8 & 43.3 & 13 & Local & \multirow{2}{*}{} \\
\hline 72.4 & 27.6 & 26.7 & 8 & Imported \\
\hline 100.0 & 27.6 & 26.7 & 8 & Both & \\
\hline & 100.0 & 96.7 & 29 & Total & \\
\hline & & 3.3 & 1 & Missing \\
\hline \hline
\end{tabular}

TABLE (7): LABOR PRODUCTIVITY

\begin{tabular}{|c|c|c|c|c|c|}
\hline \multicolumn{6}{|c|}{ Did the labor produce work as how it was planned } \\
\hline Cumulative Percent & Valid Percent & Percent & Frequency & & \\
\hline 32.1 & 32.1 & 30.0 & 9 & Yes & \multirow[t]{4}{*}{ Valid } \\
\hline 78.6 & 46.4 & 43.3 & 13 & No & \\
\hline \multirow[t]{4}{*}{100.0} & 21.4 & 20.0 & 6 & Sometimes & \\
\hline & 100.0 & 93.3 & 28 & Total & \\
\hline & & 6.7 & 2 & System & Missing \\
\hline & & 100.0 & 30 & Total & \\
\hline
\end{tabular}

$43.3 \%$ said labor productivity was not as planned, $30 \%$ said, yes, the labor productivity was as planned, $20 \%$ said it was sometimes, and $6.7 \%$ is missing data.as shown in table( 7). So to increase the productivity rate we can use one of the following:
1- Two or more shifts instead of one.

2- Apply overtime increase in shift's period up to 10 hours instead of 8 .

3- Increase the use of resources; labor and equipment.

TABLE (8) EQUIPMENT AVAILABILITY

\begin{tabular}{|c|c|c|c|c|c|}
\hline \multicolumn{6}{|c|}{ Has the equipment been used in the activities requiring them } \\
\hline Cumulative Percent & Valid Percent & Percent & Frequency & & \\
\hline 93.3 & 93.3 & 93.3 & 28 & Yes & \multirow[t]{3}{*}{ Valid } \\
\hline \multirow[t]{2}{*}{100.0} & 6.7 & 6.7 & 2 & No & \\
\hline & 100.0 & 100.0 & 30 & Total & \\
\hline \multicolumn{6}{|c|}{ TABLE (9): COMMUNICATION BETWEEN OWNER AND CONSULTANT } \\
\hline \multicolumn{6}{|c|}{ Your of owner/consultant communication } \\
\hline Cumulative Percent & Valid Percent & Percent & Frequency & & \\
\hline 26.7 & 26.7 & 26.7 & 8 & Excellent & \multirow[t]{3}{*}{ Valid } \\
\hline 73.3 & 46.7 & 46.7 & 14 & Good & \\
\hline \multirow[t]{2}{*}{100.0} & 26.7 & 26.7 & 8 & Medium & \\
\hline & 100.0 & 100.0 & 30 & Total & \\
\hline
\end{tabular}

TABLE (10): CONTRACTOR PAYMENT

\begin{tabular}{l|l|l|l|l|l}
\hline \hline \multicolumn{2}{l}{ When were the due payments paid to the contractor } & \multicolumn{2}{l}{} \\
\hline Cumulative Percent & Valid Percent & Percent & Frequency & \multicolumn{2}{l}{ Valid } \\
& & & & Monthly & \\
\hline 20.0 & 20.0 & 20.0 & 6 & Every 3 months \\
\hline 26.7 & 6.7 & 6.7 & 2 & After every stage \\
\hline 80.0 & 53.3 & 53.3 & 16 & Other \\
\hline 100.0 & 20.0 & 20.0 & 6 & Total & \\
\hline \hline
\end{tabular}

$20 \%$ said the payment to contractor is monthly

93\% answered, yes, equipment was used, while $6.7 \%$ said no equipment was which means that this issue isn't viewed as one of the problems of construction in Sudan.as shown in table (8).

$26.7 \%$ said the communication between owner and consultant is excellent, $46.7 \%$ think it is good, while $26.7 \%$ think it is medium.as shown in table (9). based, $6.7 \%$ replied that payment takes place every 3 months, and more than half: 53.3\% answered that payment is done by the end of each stage of the project .as shown in table(10).

Each construction contract governed by this section must define within the contract a monthly billing cycle for the contractor to submit monthly progress payment progress requests and final 
payment requests to the owner. The contractor should submit payments requests to the owner. Payment requests must be based upon actual or estimated work performed and materials supplied the preceding monthly billing cycle. The requirement does not preclude an owner from mutually agreeing with the contractor to prepay for materials. The owner is considered to have received a payment request when the payment request is submitted to any person designated by the owner in the contract to receive the payment request. So the request must be first review by the consultant and that takes period. So, most answers say that payment comes after every stage, as the questionnaire shows.

Contractors affect in delay by $56.7 \%$ as some

TABLE (11): CONTRACTOR AFFECT IN DELAY

\begin{tabular}{|c|c|c|c|c|c|}
\hline \multicolumn{6}{|c|}{ Did the contractor have an effect in the delay } \\
\hline Cumulative Percent & Valid Percent & Percent & Frequency & & \\
\hline 56.7 & 56.7 & 56.7 & 17 & Yes & \multirow[t]{3}{*}{ Valid } \\
\hline \multirow[t]{2}{*}{100.0} & 43.3 & 43.3 & 13 & No & \\
\hline & 100.0 & 100.0 & 30 & Total & \\
\hline
\end{tabular}

The researcher will discuss only the reasons that highly contribute in the delay:

1. The delay from contractors may occur because the lake of distributions for the labors and equipment is a priority.

2. Personal relationship between owner and contractor could negatively affect the management of the project.

3. Changes in design, cancelling contractors or changing all these actions cause delays.

\section{CONCLUSIONS AND RECOMMENDATIONS}

\subsection{Conclusions} and apply the corrective or preventive actions. respondents answered while 43.3\% think they don't affect in delay.as shown in table (11).

Contractor related factors include site management, improper planning, inadequate contractor experience, mistakes during construction methods and delay caused by subcontractors. Delays caused by subcontractors are included among the contractor's factors because the latter is fully responsible for the delays caused by his subcontractors.

In addition to the previous tables and percentages read, there was a separate paragraph containing additional reasons for delay, shown in the table (12).

1- The construction firms should train their engineers to use these tools to control the time

2- The construction firms to train their projects participants to raise the effectiveness of the project performance and use foreign labors in the project for limited short period just to educate local labors Discipline activity.

TABLE (12): GENERAL REASONS OF CONTRACTOR DELAY

\begin{tabular}{l|l|l|l|l|}
\hline \hline Cumulative Percent & Valid Percent & Percent & Frequency & \\
\hline 3.3 & 3.3 & 3.3 & 1 & Economic conditions of the country \\
\hline 6.7 & 3.3 & 3.3 & 1 & The owner's holdbacks \\
\hline 10.0 & 3.3 & 3.3 & 1 & $\begin{array}{l}\text { Bad relationship between company's } \\
\text { owner and the management }\end{array}$ \\
\hline 13.3 & 3.3 & 3.3 & 1 & Weak concrete results \\
\hline 20.0 & 6.7 & 6.7 & 2 & Not caring for the time schedule \\
\hline 23.3 & 3.3 & 3.3 & 1 & Contractor has other incomplete projects \\
\hline 40.0 & 16.7 & 16.7 & 5 & Not enough labor \\
\hline 80.0 & 40.0 & 40.0 & 12 & n/a \\
\hline 83.3 & 3.3 & 3.3 & 1 & Contractor hasn't used any tools \\
\hline 93.3 & 10.0 & 10.0 & 3 & Not caring for material \\
\hline 100.0 & 6.7 & 6.7 & 2 & Imported material's delivery \\
\hline \hline
\end{tabular}


3- The parties should include this item in contract to shed a light on how this may cause a delay or affect the whole time.

4- The owner to be very serious in the right time when the contractor deserves the payment. To early plan for it and have a sufficient time to provide its availability.

5- The construction firms to use the technique developed in this study to evaluate their projects situation with scheduling in order to monitor and control the project

\section{Estimating the Tender}

Bill of Quantities (BOQ) and Specifications .Comprehensive and objective estimates are the start of sound construction management and cost control. Architects, owners, and contractors are aware of the need for well-prepared estimates during each phase of a project. The construction estimating service must include:-

- Budget, estimates.

- Preliminary (system) estimates.

- Detailed quantity surveys.

2. Type of contract:

Companies top manager as decisions

\section{Payment time:}

The contract may specify that either the owner or a 'specified person' may issue the notice to the contractor, or the contractor may issue the payment notice to the owner.

This payment notice must be issued within enough periods to let the consultant review the payment before the payment date

'Specified person' means a person specified in or determined in accordance with the provisions of the contract - typically this will be the person administering the contract on behalf of the Employer.

4. Political order: Many societies use labor market coordination to maximize economic growth and equality, yet employers' willing cooperation with government and labor is something of a mystery.

\section{5-Project complete documents:}

It is the claimant's obligation to prove its claim. If he cannot do so, he will not prevail. Alternatively, complete records will be necessary to defeat an owner's delay claim. The lack of complete business records can result in additional costs in proving or disproving a construction claim.

\subsection{Recommendations}

1- The construction firms should train their engineers to use these tools to control the time and apply the corrective or preventive actions.

2- The construction firms to train their projects participants to raise the effectiveness of the project performance and use foreign labors in the project for limited short period just to educate local labors Discipline activity.

3- The parties should include this item in contract to shed a light on how this may cause a delay or affect the whole time.

4 - The owner to be very serious in the right time when the contractor deserves the payment. To early plan for it and have a sufficient time to provide its availability.

5- The construction firms to use the technique developed in this study to evaluate their projects situation with scheduling in order to monitor and control the project

\section{REFERENCES}

[1] Michael T. Callahan and H. Murray Honsel, "Construction Schedules: Analysis, Evaluation and Interpretation of Schedules in Ligation and Dispute Resolution", 4th Edition Juris Publishing June 2011.

[2] Michael T. Callahan ,"Construction Change Order Claims", Aspin Publishers Online, 2005.

[3] Amir Hossein Alarifar, "Identification Evaluation and Classification of Time Delay Risks of Construction Project", Iran 2014

[4] G. Sweis, R.S, Delays in Construction Projects "The Case of Jordan International of Project", 2008.

[5] Wiely- Black Well Winch, "Managing Construction Projects", 2nd Publishing, 2009.

[6] Fellows R.Lru A," Research Method for Construction", 3rd ed. Blackwell, 2008.

[7] Barry B .Bramble and Michael T.Callahan 1; "Construction Delay Claims", Aspin Publishers Oct 2010.

[8] Sidney levg and George Ritz, "Total Construction Project Management", Second Edition. New York 2002.

[9] Wald Gaber Mohamed Hakami and Mohamed Ibrahim Yousif, "The Effect of electrical Factor in Construction Project Performance in Sudan ", Sudan University of Science and Technology November 2012.

[10] Thomas J.Driscoll and FeMAA Senior Vice President, "The Important of Time Management ",Hill International 2004 